\title{
Short-day photoperiods affect expression of genes related to dormancy and freezing tolerance in Norway spruce seedlings
}

\author{
Elisabeth Wallin $^{1,2}$ (D) Daniel Gräns ${ }^{1,2}$ - Douglass F. Jacobs ${ }^{3}$ - Anders Lindström ${ }^{1,2}$ • \\ Nathalie Verhoef ${ }^{4}$
}

Received: 20 February 2017 / Accepted: 4 July 2017 / Published online: 1 August 2017

(C) The Author(s) 2017. This article is an open access publication

\begin{abstract}
- Key Message Gene expression analysis showed that prolonged short day (SD) treatment deepened dormancy and stimulated development of freezing tolerance of Picea abies seedlings. Prolonged SD treatment also caused later appearance of visible buds in autumn, reduced risks for reflushing, and promoted earlier spring bud break.

- Context Short day (SD) treatment of seedlings is a common practice in boreal forest tree nurseries to regulate shoot growth and prepare the seedlings for autumn planting or frozen storage. - Aims The aim of this study was to examine responses of Norway spruce (Picea abies (L.) Karst.) to a range of SD treatments of different length and evaluate gene expression related to dormancy induction and development of freezing tolerance. - Methods The seedlings were SD treated for $11 \mathrm{~h}$ a day during 7, 14, 21, or 28 days. Molecular tests were performed, and the expression profiles of dormancy and freezing
\end{abstract}

Handling Editor: Michael Tausz

Contribution of the co-authors Elisabeth Wallin performed all experimental work, analyzed the data, and co-wrote the manuscript.

Daniel Gräns contributed in data interpretation and co-wrote the manuscript.

Anders Lindström supervised the work and co-worked in paper writing. Nathalie Verhoef was responsible for gene activity analyses.

D.F. Jacobs participated in data interpretation and paper writing.

Elisabeth Wallin

ewa@du.se

Daniel Gräns

dga@du.se

Douglass F. Jacobs

djacobs@purdue.edu

Anders Lindström

ali@du.se tolerance-related genes were analyzed as well as determination of shoot growth, bud set, bud size, reflushing, dry matter content, and timing of spring bud break.

- Results The 7-day SD treatment was as effective as longer SD treatments in terminating apical shoot growth. However, short (7 days) SD treatment resulted in later activation of dormancy-related genes and of genes related to freezing tolerance compared to the longer treatments which had an impact on seedling phenology.

- Conclusion Gene expression analysis indicated an effective stimulus of dormancy-related genes when the SD treatment is prolonged for at least 1-2 weeks after shoot elongation has terminated and that seedlings thereafter are exposed to ambient outdoor climate conditions.

Keywords Picea abies · Molecular tests · Photoperiod · Shoot growth termination $\cdot$ Bud formation $\cdot$ Storability

Nathalie Verhoef

nathalie.verhoef@nsure.nl

1 Dalarna University, 79188 Falun, Sweden

2 School for Forest Management, Swedish University of Agricultural Sciences, Box 43, 73921 Skinnskatteberg, Sweden

3 Department of Forestry and Natural Resources, Purdue University, West Lafayette, IN 47907-2061, USA

4 NSure, Binnenhaven 5, 6700 AA Wageningen, The Netherlands 


\section{Introduction}

The quality of nursery seedling stock plays an important role in determining reforestation success (Mattsson 1997). One key attribute toward the end of nursery cultivation is dormancy status, which affects seedling stress resistance during lifting and handling, and freezing storability (Stattin et al. 2000). Early development of adequate seedling freezing tolerance may be important to reduce risks during autumn planting, which may provide an effective means to extend the planting season yet can be problematic for frost-sensitive species such as Norway spruce (Picea abies (L.) Karst.) (Christersson 1978; Kohmann and Johnsen 2007).

The dormancy cycle of many boreal forest tree species is strongly affected by seasonal changes in photoperiod (Ekberg et al. 1979) and temperature (Heide 1974). Short day (SD) treatment (Rosvall-Åhnebrink 1982; Fløistad and Granhus 2010, 2013) of seedlings has shown to be an effective tool to regulate height growth while also inducing dormancy. This treatment involves reducing the photoperiod in late summer using black curtains that completely cover the seedlings either inside the greenhouses or outdoors in specially equipped areas. The intensity and duration of SD treatments vary widely across regions and nurseries, but typically fall within a range of 8-12 h of photoperiod for 14-35 days (Rosvall-Åhnebrink 1982; Konttinen et al. 2003; Jacobs et al. 2008; Luoranen et al. 2009; MacDonald and Owens 2010; Fløistad and Granhus 2013). SD treatment promotes early growth cessation and induces bud set (Dormling et al. 1968; Heide 1974; Ekberg et al. 1979; Colombo et al. 1989, 2001; Fløistad and Granhus 2013), while also increasing seedling freezing tolerance (Dormling 1982; Colombo et al. 1989, 2001; Jacobs et al. 2008). Thus, this cultural treatment is now regularly employed in container nurseries across Canada and Scandinavia in production of boreal conifers (Colombo et al. 2001).

SD treatments vary in their effects in seedling growth and development depending on cultural conditions, species, and provenance (Dormling et al. 1968). The dates for start and termination of SD treatment are important because bud dormancy is promoted if the natural critical night length (i.e., night length known to promote bud set of a given provenance) is reached by the end of treatment (Kohmann and Johnsen 2007) and this prevents reflushing (Fløistad and Granhus 2010, 2013). The required natural critical night length varies by provenance, whereby northern provenances and those from high altitudes need shorter night lengths to induce dormancy compared to southern provenances from lower altitudes (Dormling 1973; Heide 1974; Dormling 1979; Dormling and Lundkvist 1983; Clapham et al. 1998). This suggests that different provenances will respond variably to different timing and durations of SD treatments. Fløistad and Granhus (2013) showed that SD treatment $(7,10,14$, and 17 days) of Norway spruce (origin $60^{\circ} \mathrm{N}, 10^{\circ} \mathrm{E}$ ) significantly affected height growth after just 7 days of treatment. Their results among others also suggest that Norway spruce seedlings require a longer SD treatment to avoid a second bud flush, especially if the treatment starts early (Heide 1974; Fløistad and Granhus 2010, 2013; Luoranen and Rikala 2015). Furthermore, Olsen et al. (2014) reported that different day and night temperatures during SD treatment variably affected bud development.

If $\mathrm{SD}$ treatments are too extensive (i.e., duration and/or intensity), reduced photosynthesis may lead to a decline of seedling growth and vigor. MacDonald and Owens (2010), working with Douglas-fir (Pseudotsuga menziesii var. menziesii (Mirb.) Franco), recommended SD treatments lasting for 3 weeks (vs 4-6 weeks) to avoid reductions in shoot diameter and root mass. Similarly, Konttinen et al. (2003, 2007) found that prolonging daily light periods from 8 to 12-14 h during SD treatment resulted in better seedling performance for provenances of northern Norway spruce (origin $\left.60^{\circ} 40^{\prime} \mathrm{N}-64^{\circ} 40^{\prime} \mathrm{N}\right)$.

Determination of growth cessation and bud status is relatively straightforward, while the estimation of dormancy level and its relationship to subsequent freezing tolerance is more complex. To our knowledge, even though SD treatment has been used for several decades, there is still no practical way to assess dormancy level and its relationship to the development of subsequent freezing tolerance during ongoing SD treatment. Enhanced knowledge of how patterns of gene expression correspond with phenological attributes, such as freezing tolerance of seedlings, allows the possibility to use molecular tests to postpone effects of environmental changes. Freezeinduced electrolyte leakage provides a direct measure of seedling freezing tolerance (Lindström et al. 2014); yet, development of freezing tolerance lags behind dormancy development (Weiser 1970; Fushigami and Nee 1987; Dormling 1993; Clapham et al. 2001; Greer et al. 2001; Holliday et al. 2008), and so, its application is limited to several weeks after completion of SD treatment. Previous studies have investigated gene expression connected to dormancy and freezing tolerance induced by SD treatment of species such as Norway spruce (Asante et al. 2011), Sitka spruce (Holliday et al. 2008), and Douglas-fir (Balk et al. 2008). In 2006, NSure (Wageningen, The Netherlands) marketed a testing procedure for Norway spruce (ColdNSure ${ }^{\mathrm{TM}}$ ). This molecular test measures the activity of a set of genes involved in development of freezing tolerance (Joosen et al. 2006; Stattin et al. 2012). The ColdNSure ${ }^{\mathrm{TM}}$ test, based on the relationship between the outcome of freezing shoots to $-25{ }^{\circ} \mathrm{C}$ and the expression of freezing tolerance-related genes, has been shown to be as effective as freeze-induced electrolyte leakage in predicting freezing tolerance and storability of Norway spruce (Stattin et al. 2012). Furthermore, Stattin et al. (2011) identified dormancy-related genes that respond upon SD treatment in Norway spruce. These sets of genes could possibly be used as a predictive tool to measure dormancy development during 
SD treatment and help nurseries to decide when it is appropriate to terminate the treatment. The ColdNSure ${ }^{\mathrm{TM}}$ test could be used as an indicator of which SD program results in favorable development of freezing tolerance and storability for a given species and provenance.

Following planting, seedlings are susceptible to frost damage after bud break (Dormling 1982; Christersson and von Fircks 1988). The timing of bud break in spring is largely affected by temperature accumulation (Hannerz 1994; Sutinen et al. 2012), but other factors, such as photoperiod and temperature during growth cessation and bud set, are also important (Sögaard et al. 2007; Fløistad and Granhus 2010). Konttinen et al. (2003) reported that SD treatment initiated in the beginning of July with a duration of 3-4 weeks led to earlier apical bud break in spring and thereby increased exposure to frost damage compared to seedlings subjected to shorter (2-3 weeks) SD treatment with starting dates in midAugust. Sögaard et al. (2007) and Olsen et al. (2014) showed that high temperature during SD treatment resulted in a later bud break the following spring. It is possible that the activity level of dormancy-related genes during growth cessation could effectively forecast the timing of bud burst in spring.

The overall aim of this study was to investigate how the activity of genes related to dormancy and freezing tolerance influence the physiological responses of SD-treated seedlings. Additionally, we sought to determine whether the gene expression profiles could be used to forecast seedling development (i.e., termination of growth, bud set, freezing tolerance, and timing of bud burst).

Our study hypotheses were that (i) the genes that are activated by SD treatment for developing dormancy can act as an indicator for SD treatment termination, (ii) different durations of SD treatment, and (iii) different conditions obtained indoors and outdoors after termination of SD treatment will affect gene- and physiological seedling responses.

\section{Materials and methods}

\subsection{Seedling material and treatments}

The experimental material consisted of container-grown 1.5year-old seedlings of Norway spruce cultivated at Nässja nursery $\left(60^{\circ} 15^{\prime} \mathrm{N} ; 16^{\circ} 50^{\prime} \mathrm{E}\right)$, Sweden. The seeds were collected in the seed orchard Ålbrunna $\left(59^{\circ} 31^{\prime} \mathrm{N}\right.$, alt. $\left.50 \mathrm{~m}\right)$, with mean origin of the plus trees corresponding to lat. $60^{\circ} 58^{\prime} \mathrm{N}$, alt. $212 \mathrm{~m}$. The seeds were sown on July 13, 2012 in 50-ml containers at a density of 820 cavities $\mathrm{m}^{-2}$ (Plantek 121, Finland), filled with peat (NMP Närkes AB, Sweden) and grown according to standard routines at Nässja nursery. A total of 24 container units each consisting of $11 \times 11$ cavities were transferred from the Nässja nursery on July 9, 2013 and placed in the open at the research station in Vassbo $\left(60^{\circ} 31^{\prime} \mathrm{N} ; 15^{\circ} 31^{\prime}\right.$
E, alt. $130 \mathrm{~m}$ ). Seedlings were fertilized weekly by adding a complete mineral nutrient solution (Wallco, Sweden; N:P:K, 100:13:65) dissolved in the irrigation water at a rate of $3 \mathrm{~g} \mathrm{~N}$ week ${ }^{-1} \mathrm{~m}^{-2}$ through the third week of September. On July 15 , 2013, all seedlings were transferred indoors to a greenhouse except for one batch (outdoor control) consisting of four container units (replicates) that were placed outside. Another batch (control indoor), also containing four units (replicates), was placed indoors and exposed to natural day length. The remaining 16 units were split in half, resulting in 32 smaller units (each containing 55 seedlings), which were then randomly placed in the blackout compartment indoors. Seedlings were subjected to SD treatment of $11 \mathrm{~h}$ day and $13 \mathrm{~h}$ night, a commonly used blackout treatment for the selected Norway spruce provenance. According to Dormling and Lundkvist (1983), our Norway spruce provenance would have a critical night length (when $50 \%$ of the population starts to initiate bud set) of approximately $7 \mathrm{~h}$, which corresponds to a day length of $17 \mathrm{~h}$. Seedlings were SD treated for 7 days (SD 7) after which four units were moved outdoors and four units were kept indoors, with both environments providing natural day length. This procedure was repeated after 14 (SD 14), 21 (SD 21), and 28 (SD 28) days (Fig. 1). The natural day length that the SD 7 seedlings were exposed to after completion of SD treatment was $17 \mathrm{~h}$ and $38 \mathrm{~min}$, for SD 14; $17 \mathrm{~h}$ and $5 \mathrm{~min}$, SD 21; $16 \mathrm{~h} 32 \mathrm{~min}$ and SD 28; $15 \mathrm{~h} 55 \mathrm{~min}$.

\subsection{Measurements of height and bud development}

In each container unit (replicate), the middle row of 11 seedlings was marked for measurement of height and bud status. Measurements of height were performed once a week during a 4-week period (July 15 through August 12, 2013). Thereafter, measurements were made biweekly until September 23, and a final measurement was completed on October 9. Different categories (based on Krutzsch (1973) with some alterations) were used to classify apical bud set development, reflushing, and bud break. Apical bud set development was measured at the same time as height and classified as follows: no bud, initial indication of bud, small bud, and large bud. Reflushing was monitored for apical and lateral buds only on September 9 using four categories: no reflushing, bud needles visible, bud needles $<10 \mathrm{~mm}$, and bud needles $\geq 10 \mathrm{~mm}$. At the end of October 2013, outdoor-grown seedlings were transferred into the greenhouse where all seedlings were kept until May 2014 (Fig. 2). On January 24, apical bud size was measured using a caliper and classified into five categories $(1=\leq 1.0 \mathrm{~mm}, 2=1.1-2.0 \mathrm{~mm}, 3=2.1-3.0 \mathrm{~mm}$, $4=3.1-4.0 \mathrm{~mm}, 5=4.1-5.0 \mathrm{~mm})$. Apical bud break development was measured weekly from March 12 to May 2 and classified as follows: no bud break, needles visible, needles $<10 \mathrm{~mm}$, needles $\geq 10 \mathrm{~mm}$. The previously described bud development categories were combined into two major classes ( 1 and 2$)$ to simplify data analysis. This was done for bud set (no bud + initial indication of 


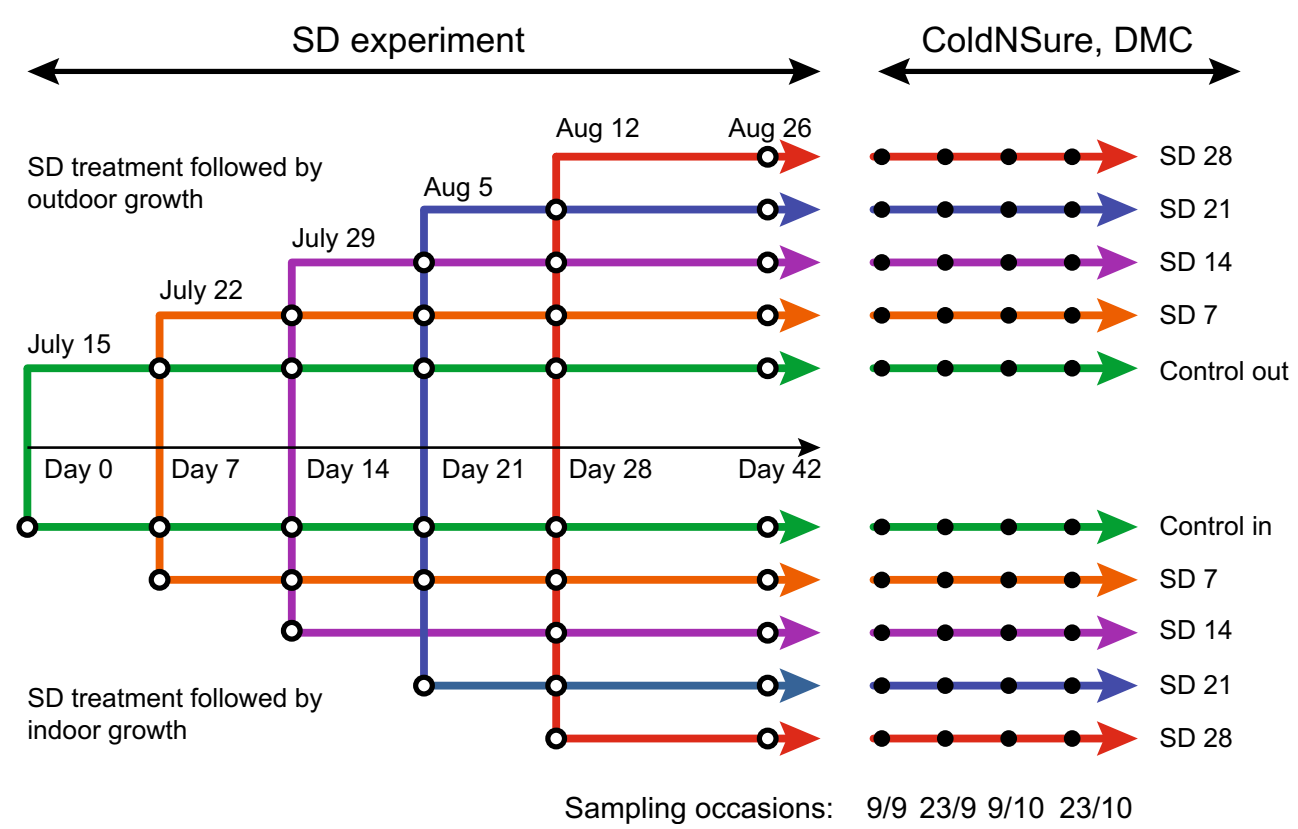

Fig. 1 Experimental design and sampling schedule for SD (short day) experiment (11 h light; $13 \mathrm{~h}$ night). Untreated control seedlings (green) were kept under natural light conditions indoors and outdoors during the experiment. For the remaining seedlings, SD treatment started on July 15, 2013 in greenhouse for all SD treatments. Seedlings were divided into four batches and subjected to four different SD treatment periods: 7 (orange), 14 (purple), 21 (blue), and 28 (red) days. Following treatment, half of each batch was moved outdoors and the other

bud $=\mathrm{S} 1$, small bud + large bud $=\mathrm{S} 2$ ), reflushing (no reflushing $=\mathrm{R} 1$, needles visible + needles $<10 \mathrm{~mm}+$ needles

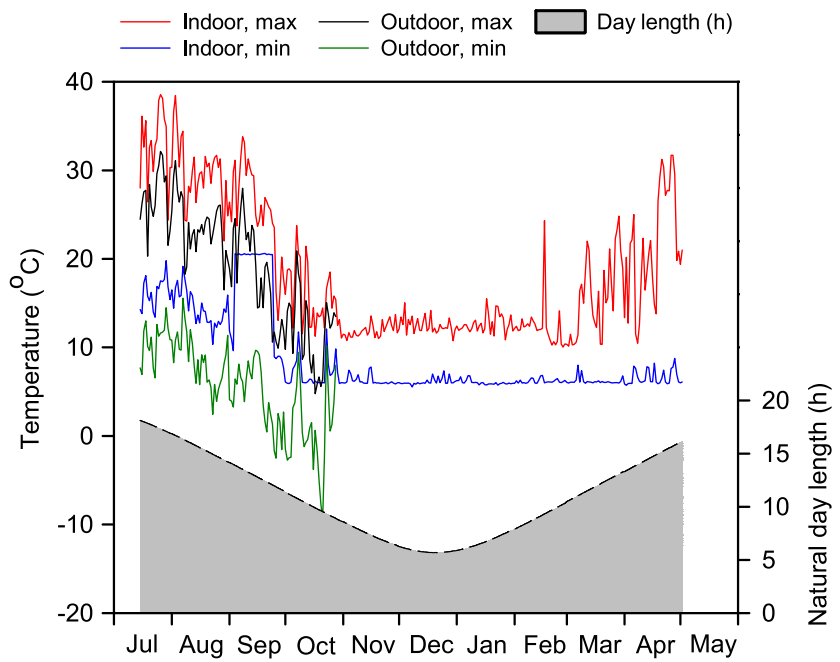

Fig. 2 Daily maximum and minimum greenhouse temperatures from July 15, 2013 to Apr. 10, 2014. Temperature measured $1.6 \mathrm{~m}$ above ground. Daily maximum and minimum outdoor temperatures from July 15 to Oct. 28,2013 . Temperature measured $1.3 \mathrm{~m}$ above ground. Seedlings grown outdoors were transferred indoors to the same greenhouse as the other seedlings on Oct. 28 for winter storage at minimum temperature of $+7{ }^{\circ} \mathrm{C}$. Natural day lengths are indicated in the figure remained indoors, all exposed to natural day length. Samples for molecular test of dormancy induction were taken each week during the SD treatment period followed by a final sample on Aug. 26 (indicated by open circles). Samples for freezing tolerance (ColdNSure $\left.{ }^{\mathrm{TM}}\right)$ were collected at four different occasions: Sept. 9, Sept. 23, Oct. 9, and Oct. 23 (indicated by solid circles). Samples for determination of DMC were taken only on Oct. 23

$\geq 10 \mathrm{~mm}=\mathrm{R} 2$ ), and bud break (no bud break $=\mathrm{B} 1$, needles visible + needles $<10 \mathrm{~mm}+$ needles $\geq 10 \mathrm{~mm}=\mathrm{B} 2$ ).

\subsection{Measurements of gene expression and dry matter content}

The gene expression profiles of the dormancy-related genes during the period of SD treatment was studied by taking samples each week starting on July 15 (day 0), July 22 (day 7), July 29 (day 14), August 5 (day 21), and August 12 (day 28) followed by a final sample on August 26 (day 42) (Fig. 1). Thereafter, samples were collected at four different occasions (Sep 9, Sep 23, Oct 9, and Oct 23) to determine the freezing tolerance and storability by the molecular ColdNSureTM test (Stattin et al. 2012). For each treatment, the top $2 \mathrm{~cm}$ of eight randomly selected seedlings were collected (two seedlings per replicate) and the needles were removed with a sharp blade to uncover the apical bud; alternatively, in case of early stages of bud development, the upper $3 \mathrm{~mm}$ of the shoot was used. The apical bud or the tip of the shoot was removed and immediately frozen in liquid nitrogen and then stored at $-80{ }^{\circ} \mathrm{C}$. General samples of the treatments (each containing eight buds) were sent to the NSure laboratory where the molecular measurements were performed. The bud tissue samples were ground in liquid nitrogen, total RNA was isolated using the Aurum Total RNA minikit (Bio-Rad), and thereafter, cDNA was synthesized using the QScript cDNA supermix (Quanta 
Biosciences). Gene expression was measured using PerfeCTa SYBR Green Supermix (QuantoBio) and the CFX96 RealTime PCR detection system (Bio-Rad) under the following conditions: denaturation at $95^{\circ} \mathrm{C}$ for $3 \mathrm{~min}$ followed by 40 cycles of amplification $\left(95^{\circ} \mathrm{C}\right.$ for $10 \mathrm{~s}$ and $60^{\circ} \mathrm{C}$ for $\left.30 \mathrm{~s}\right)$. The level of gene expression was given as delta delta threshold cycle ( $\mathrm{ddCt})$, which is the relative difference between the gene of interest and internal reference genes (i.e., genes that did not show any significant difference in expression). The dormancy-related genes for Norway spruce were previously identified by Stattin et al. (2011) by using Single-Read Next Generation Illumina Sequencing performed by ServiceXS (The Netherlands) on SD-treated seedlings from the provenance Runesten. As a reference, a de novo assembly was used as described by Stattin et al. (2012). Quantification of a gene was performed by counting the number of reads per gene of each sample. For differential analyses between the samples, DESeq (Anders and Huber 2010) was used. For this project, four potential SD indicators $(L N 2, L N 3$, $L N 4$, and $L N 6$ ) were selected, and specific primers were designed using Primer3 (http://frodo.wi.mit.edu/primer3/).

Freezing tolerance was determined by using the freezing tolerance-related genes according to the commercial molecular test (ColdNSure ${ }^{\mathrm{TM}}$ ) used by Swedish forest tree nurseries (Joosen et al. 2006; Balk et al. 2007). The genes measured were CO1, $\mathrm{CO} 4, \mathrm{CO} 8, \mathrm{CO} 9$, and $\mathrm{CO} 10$. The corresponding freezing tolerance status was calculated by NSure using a model for Norway spruce similar to the model presented for Douglas-fir (Balk et al. 2008) and expressed as four different phases: ColdNSure ${ }^{\mathrm{TM}}$ phase $0=$ cold sensitive and the indicator profiles match the profiles of lots that are actively growing; no sign of freezing tolerance can be recognized. Phase $1=$ developing freezing tolerance; early signs of freezing tolerance development can be recognized. Phase 2 = developing freezing tolerance; approaching full freezing tolerance. Phase 3 = freezing tolerant; the indicator profiles match the profiles of lots that have ceased growth and are fully tolerant, ready for lifting and storage.

On October 23, in addition to the ColdNSure ${ }^{\mathrm{TM}}$ test, we used a method described by Rosvall-Åhnebrink (1985) to determine seedling storability by assessing dry matter content (DMC) in the upper $2 \mathrm{~cm}$ of five shoots per replicate. As reported by Rosvall-Åhnebrink (1985), the DMC should be between 35 and $38 \%$ for 1-year-old spruce seedlings to be classified as storable. The upper target level should be applied for seedlings that are SD treated.

\subsection{Environmental measurements}

Temperatures during the experimental period were measured using calibrated sensors attached to a data logger (Campbell Scientific CR1000, UK) measuring every $5 \mathrm{~min}$ and producing 15-min averages. Temperature indoors was measured $1.6 \mathrm{~m}$ above ground by a sensor placed in a ventilated radiation shield. The outdoor sensor was placed $1.3 \mathrm{~m}$ above ground in a ventilated radiation shield. Daily indoor and outdoor values are presented in Fig. 2. During July, August, and the first days of September 2013, the heating system was turned off. When heating was turned on, the control system for regulation of temperature in the greenhouse was not functioning satisfactorily during a 3-week period in September. As a result, the minimum temperatures indoors were above $+20^{\circ} \mathrm{C}$ (Sep 3-Sep 25). From the end of September, to avoid freezing, the heating system of the greenhouse was activated at temperatures below $+7^{\circ} \mathrm{C}$.

\subsection{Statistical analysis}

Analysis of variance (ANOVA) was performed if the data fulfilled the requirements of normal distribution and constant variance. A general linear mixed hierarchical model with a nested design was used (PROC MIXED) (SAS Institute Inc. 2002-2008) for shoot growth data obtained during the first and the second week after starting the SD treatment:

$\mathrm{Y}_{\mathrm{ijk}}=\mu+\mathrm{T}_{\mathrm{i}}+\mathrm{R}_{\mathrm{ij}}+\mathrm{e}_{\mathrm{ijk}}$

where $Y_{i j k}$ is the dependent variable (the shoot growth observation of the $k$ th seedling of the $j$ th replication in $i$ th treatment) for the first and second week, respectively, after starting the SD treatment, $\mu$ is the overall mean for shoot growth, $T_{i}$ is the fixed effect of the $i$ th treatment $(i=1,2 \ldots, 10)$ where the treatments used are the 5 SD treatments for indoor and outdoor growth, respectively, $\mathrm{R}_{\mathrm{ij}}$ is the random effect of the $j$ th unit of replication (the jth container unit, $\mathrm{j}=1,2 \ldots, 4)$ within treatment $i$; from each replication, 11 seedlings were measured, and $\mathrm{e}_{\mathrm{ijk}}$ is the random error $\sim \mathrm{NID}(0$, $\sigma_{\text {e }}^{2}$ ). Where ANOVA indicated significant treatment differences $(p<0.05)$, Tukey's studentized range test was used for pairwise comparisons of treatment means $(\alpha=0.05)$. This model was used for data collected during the first and second week, respectively. For the third and fourth weeks, only standard error of the treatment means was calculated (Fig. 3), since the data was strongly skewed and contained many observations of no growth.

Bud size was analyzed separately for indoor and outdoor conditions using a general linear model (PROC GLM) (SAS Institute Inc. 2002-2008).

$\mathrm{Y}_{\mathrm{ij}}=\mu+\mathrm{SD}_{\mathrm{i}}+\mathrm{e}_{\mathrm{ij}}$

where $\mathrm{Y}_{\mathrm{ij}}$ is the dependent variable (the observation of the $j$ th seedling of the $i$ th treatment level), $\mu$ is the overall mean, $\mathrm{SD}_{\mathrm{i}}$ is the fixed effect of the $i$ th SD treatment $(i=1,2 \ldots, 5)$ for seedlings grown indoors and outdoors, respectively, and $\mathrm{e}_{\mathrm{ij}}$ is the random error $\sim \mathrm{NID}\left(0, \sigma_{\mathrm{e}}^{2}\right)$. Where ANOVA indicated significant treatment differences $(p<0.05)$, Tukey's studentized range test was used for pairwise comparisons of treatment means $(\alpha=0.05)$.

DMC values were evaluated using a $t$ test (PROC TTEST) $(p<0.05)$ (SAS Institute Inc. 2002-2008). Differences in bud 

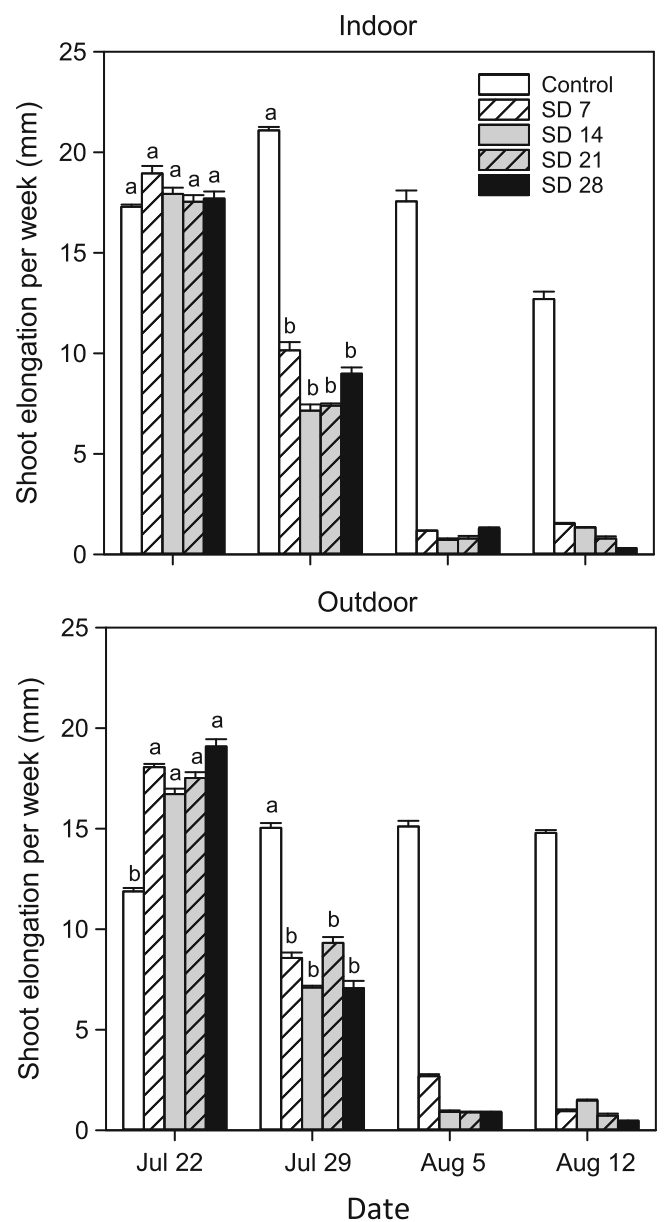

Fig. 3 Mean weekly apical shoot elongation of seedlings kept indoors and seedlings transferred outdoors after termination of SD (short day) treatment, which was done in an indoor blackout compartment. SD treatments $(7,14,21$, and 28 days) with a photoperiod of $11 \mathrm{~h}$ started on July 15 (day 0 ). Seedlings were then measured on July 22 (day 7), July 29 (day 14), Aug. 5 (day 21), and Aug. 12 (day 28). Control seedlings were kept under natural day lengths, both indoors and outdoors. Total number of seedlings in each treatment $=44, n=4$ (each replicate contains 11 seedlings). Data were analyzed independently for the first and second week after starting the SD treatment and different letters therein indicate significant differences among treatments at $p \leq 0.05$ according to Tukey's test. Vertical lines represent the standard error. For the third and fourth week, ANOVA could not be performed due to skewed distribution; only standard error of treatment means was calculated

set and bud break were analyzed by using the Chi-square test $(p<0.05)$ in Microsoft Excel (2013).

\section{Results}

\subsection{Shoot growth}

As expected, there were no significant differences in shoot elongation between SD-treated seedlings during the first 7 days in the blackout compartment. Seedlings moved from the blackout compartment after 7, 14, 21, and 28 days to natural day length conditions for growth either indoors or outdoors showed similar elongation of shoots. For SD-treated seedlings, shoot growth during the third and fourth week had almost declined to zero (Fig. 3). Shoot growth of control seedlings was larger than for SD-treated seedlings with the exception of the first 7 days. After August 12 (4 weeks after SD treatment started), biweekly measurements showed that most of the outdoor-grown control seedlings continued growing until mid-September (data not shown).

\subsection{Bud set and bud size}

During the first measurements (July 22, July 29, Aug 5, Aug 12), no significant differences in bud set were found among treatments (SD 7, 14, 21, 28) (data not shown). By August 26, almost all seedlings (indoor and outdoor) that had received the shortest SD treatment (SD 7) had set a visual bud (category S2) and the frequency of bud set was significantly higher than for control seedlings (Table 1). Also, on August 26, seedlings subjected to the SD 7 treatment had a significantly higher frequency of bud set compared to SD 14, 21, and 28 treated seedlings (Table 1). These differences between SD-treated seedlings persisted until the middle of September, but seedlings in all treatments showed visible apical buds toward the end of autumn. In January 2014, bud size from the shorter SD treatments (SD 7 and SD 14) and the controls remained slightly larger compared with seedlings subjected to the longer SD treatments (SD 21 and SD 28) (Fig. 4). There was a weak negative correlation between length of SD treatment and bud size. The trends were similar for both indoor $\left(R^{2}=0.17\right)$ and outdoor conditions $\left(R^{2}=0.13\right)$.

\subsection{Reflushing}

On September 9, none of the seedlings subjected to the longer (14, 21 , or 28 days) SD treatments showed any sign of reflushing, regardless of the growth environment. The controls and SD 7 treated seedlings grown indoors showed reflushing among $2.3 \%$ of apical buds and $2.3 \%$ of lateral buds (one seedling out of 44 of each category). The corresponding values for apical and lateral buds for the outdoor-grown seedlings were 11.4 and $0 \%$ for the controls and 0 and $9.1 \%$ for the SD 7 treated seedlings, respectively.

\subsection{Molecular dormancy indicators}

The three genes $L N 2, L N 3$, and $L N 4$ (Fig. 5) used as indicators of dormancy as well as $L N 6$ (data not shown) all showed that longer durations of SD treatment, i.e., SD 21 and SD 28, increased the level of gene expression compared to the shorter treatments SD 7 and SD 14. The highest levels were obtained for the seedlings grown outdoors following SD treatment (Fig. 5) indicating a deeper dormancy. When the shorter SD treatments (SD 7 and SD 14) were followed by natural day length, gene expression transiently stabilized or decreased. The gene expression levels 
Table 1 The effect of different SD treatments on bud set in indoor and outdoor conditions measured on August 26

\begin{tabular}{|c|c|c|c|c|c|c|}
\hline \multirow{2}{*}{$\begin{array}{l}\text { Pairwise comparison } \\
\text { of treatment }\end{array}$} & \multicolumn{2}{|c|}{ Indoors } & \multirow{2}{*}{$\begin{array}{l}\text { Chi-square } \\
\text { test } p \text { value }\end{array}$} & \multicolumn{2}{|c|}{ Outdoors } & \multirow{2}{*}{$\begin{array}{l}\text { Chi-square } \\
\text { test } p \text { value }\end{array}$} \\
\hline & Bud & No bud & & Bud & No bud & \\
\hline Control & 4 & 40 & $<0.001$ & 5 & 39 & $<0.001$ \\
\hline SD 7 & 41 & 3 & & 40 & 4 & \\
\hline Control & 4 & 40 & $<0.001$ & 5 & 39 & 0.156 \\
\hline SD 14 & 32 & 12 & & 10 & 34 & \\
\hline Control & 4 & 40 & 0.080 & 5 & 39 & 0.006 \\
\hline SD 21 & 10 & 34 & & 16 & 28 & \\
\hline Control & 4 & 40 & 0.398 & 5 & 39 & 0.725 \\
\hline SD 28 & 2 & 42 & & 4 & 40 & \\
\hline SD 7 & 41 & 3 & 0.011 & 40 & 4 & $<0.001$ \\
\hline SD 14 & 32 & 12 & & 10 & 34 & \\
\hline SD 7 & 41 & 3 & $<0.001$ & 40 & 4 & $<0.001$ \\
\hline SD 21 & 10 & 34 & & 16 & 28 & \\
\hline SD 7 & 41 & 3 & $<0.001$ & 40 & 4 & $<0.001$ \\
\hline SD 28 & 2 & 42 & & 4 & 40 & \\
\hline
\end{tabular}

Bud set had occurred if a small or large visible bud was detected (category S2, see "Materials and methods"). Pairwise comparisons were performed using a $\chi^{2}$-test. Significant differences at the $\leq 0.05$ level are marked in italics. $N=44$ seedlings measured at day 42 were similar for SD 21 and SD 28. At this final sampling date, all selected dormancy-related genes showed higher levels of gene expression in all SD treatments compared to the untreated control.

\subsection{Freezing tolerance determined by gene expression}

According to the molecular ColdNSure ${ }^{\mathrm{TM}}$, test seedlings need to reach phase 3 to be classified as freezing tolerant and storable (Fig. 6). Seedlings left indoors only reached freezing tolerance phase 1 except for treatment SD 28, which reached phase 2 on October 23, the last date of sampling. All SDtreated seedlings subjected to outdoor conditions had reached freezing tolerance phase 1 on September 9, the first date of

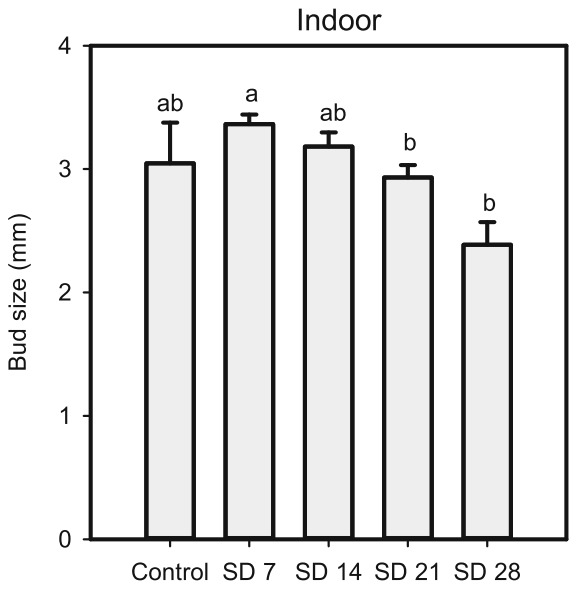

Fig. 4 Average apical bud size resulting from various lengths of SD (short day) treatment $(11 \mathrm{~h}$ light; $13 \mathrm{~h}$ night) for seedlings grown indoors and outdoors. Measurements were performed on January 24, 2014 and classified into five different categories $(1=\leq 1.0 \mathrm{~mm}$, $2=1.1-2.0 \mathrm{~mm}, 3=2.1-3.0 \mathrm{~mm}, 4=3.1-4.0 \mathrm{~mm}, 5=4.1-5.0 \mathrm{~mm})$. sampling, while the control seedlings were still in phase 0 (Fig. 6). At the second date of sampling, September 23, all SD-treated seedlings outdoors, except SD 7, reached freezing tolerance phase 2 . At the final two sampling occasions, October 9 and October 23, all SD-treated seedlings outdoors had reached phase 3 and were therefore classified as storable. The outdoor control seedlings, however, did not reach phase 3 of the ColdNSure ${ }^{\mathrm{TM}}$ test until the final sampling date.

Gene $C O 1$, used in the ColdNSure ${ }^{\mathrm{TM}}$ test for estimating freezing tolerance, showed a different pattern of gene expression during the autumn between seedlings grown indoors and outdoors (Fig. 7). A clear trend was observed outdoors indicating that longer SD treatments resulted in higher levels of gene expression suggesting improved freezing tolerance (Fig. 6). Gene expression was

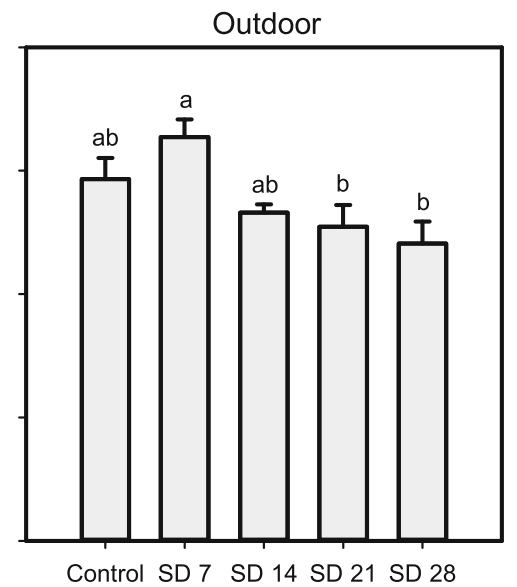

Total number of seedlings in each treatment $=44, n=4$ (each replicate contains 11 seedlings). Data were analyzed independently for the indoorand outdoor-growth environments and different letters indicate significant differences among treatments at $p \leq 0.05$, according to Tukey's test. Vertical lines represent the standard error 
Fig. 5 Gene expression profiles of $L N 2(\mathbf{a}, \mathbf{b}), L N 3(\mathbf{c}, \mathbf{d})$, and $L N 4$ $(\mathbf{e}, \mathbf{f})$ used for indicating dormancy induction. The level of gene expression is given as delta delta threshold cycle (ddCt), which is the relative difference between the gene of interest and reference genes (genes that did not show any significant difference in expression). SD (short day) treatments $(7,14,21$, and 28 days) with a photoperiod of $11 \mathrm{~h}$ started on July 15 . Measurements were performed on July 15 (day 0), July 22 (day 7), July 29 (day 14), Aug. 5 (day 21), and Aug. 12 (day 28) and on Aug. 26 (day 42). After termination of SD treatment, the Norway spruce seedlings were either kept indoors $(\mathbf{a}, \mathbf{c}, \mathbf{e})$ or moved outdoors $(\mathbf{b}, \mathbf{d}, \mathbf{f})$. Each sampling day, eight apical buds were collected from each SD treatment and growing environment and then analyzed for gene expression as one general sample

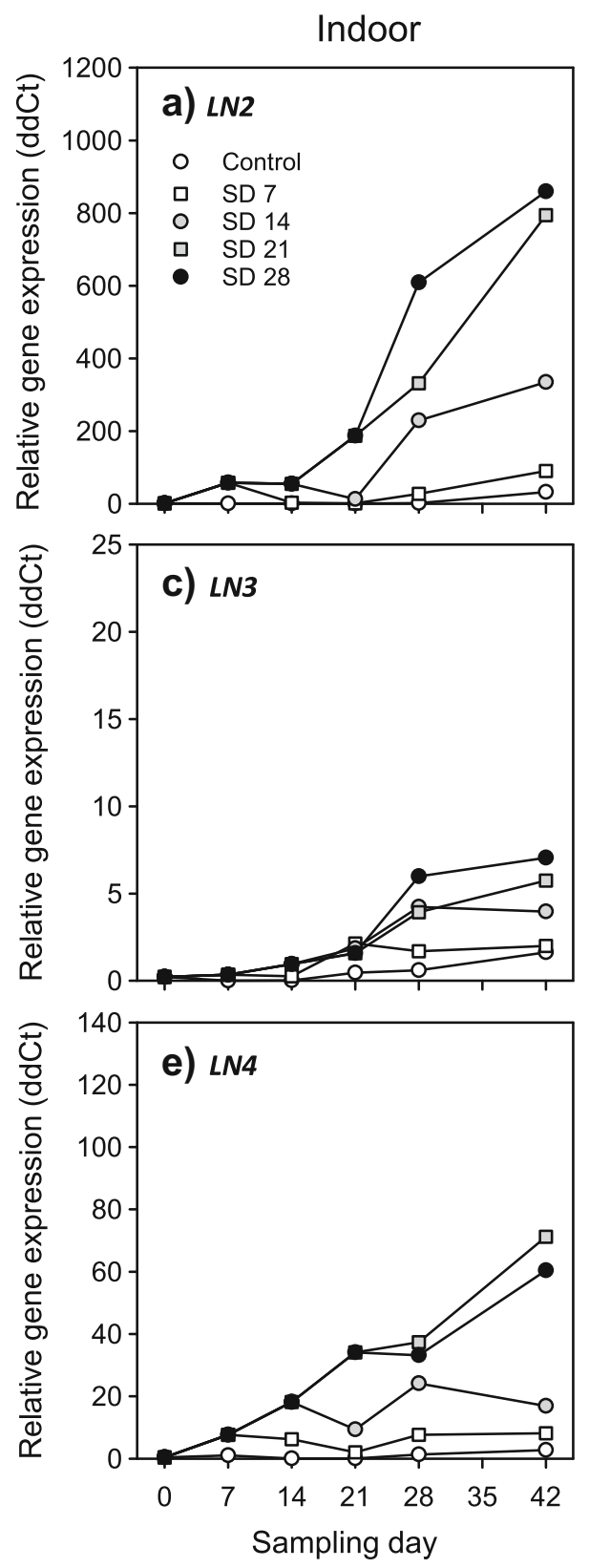

Outdoor
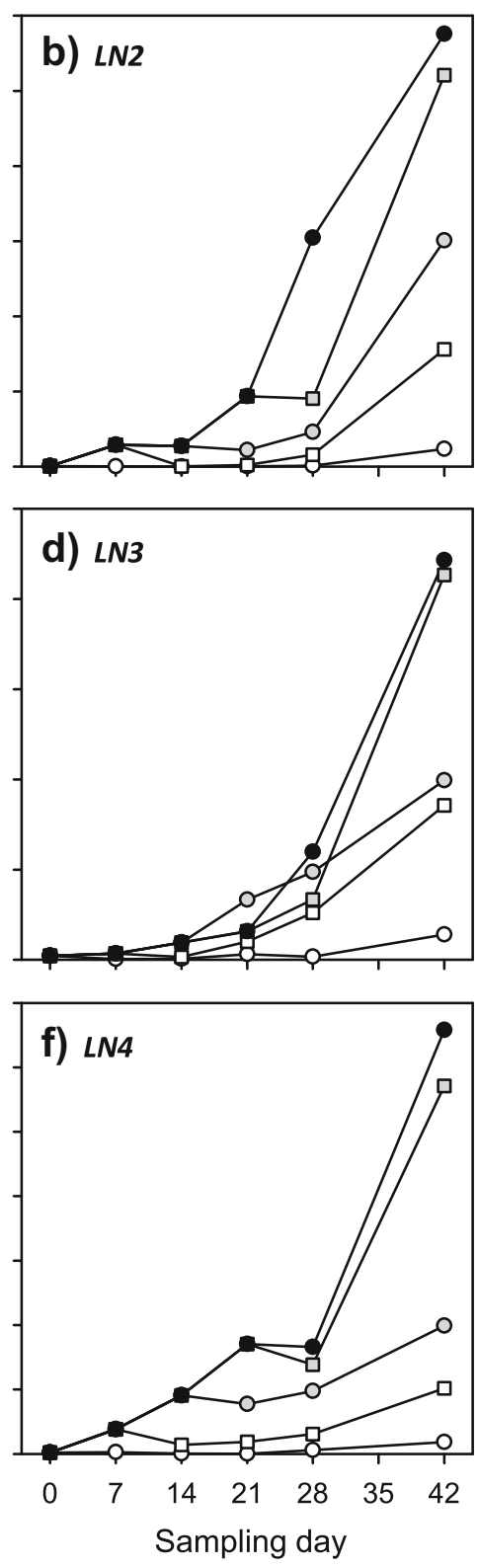

generally very low among seedlings grown indoors at all sampling dates. Similar trends were observed in data from other freezing tolerance-related genes $(\mathrm{CO} 4, \mathrm{CO}, \mathrm{CO} 9, \mathrm{CO} 10)$ used in the ColdNSure $^{\mathrm{TM}}$ test (data not shown).

\subsection{Dry matter content}

On October 23, indoor-grown seedlings showed generally low DMC values whereas seedlings grown outdoors displayed considerably higher DMC values (Fig. 8). All seedlings grown outdoors showed significantly $(p<0.001)$ higher DMC values than the target value for storability for untreated seedlings (DMC 35\%). Only outdoor-grown SD-treated seedlings reached the target value for SD-treated seedlings (DMC
$38 \%$ ). None of the treatments that were grown indoors reached the target level for storability.

\subsection{Bud break forthcoming spring}

Bud break occurred earlier for a larger proportion of seedlings grown outdoors compared to indoor-grown seedlings (Fig. 9). A varying number of seedlings in all treatments except SD 7 indoors had initiated bud break on April 3. A specific analysis of data from this date showed that a larger proportion of seedlings subjected to the longer (SD 21 and SD 28) treatments broke bud earlier compared to shorter (SD 7 and SD 14) treatments ( $p<0.001$ in both environments). A significantly $(p<0.001)$ larger proportion of control seedlings from the 

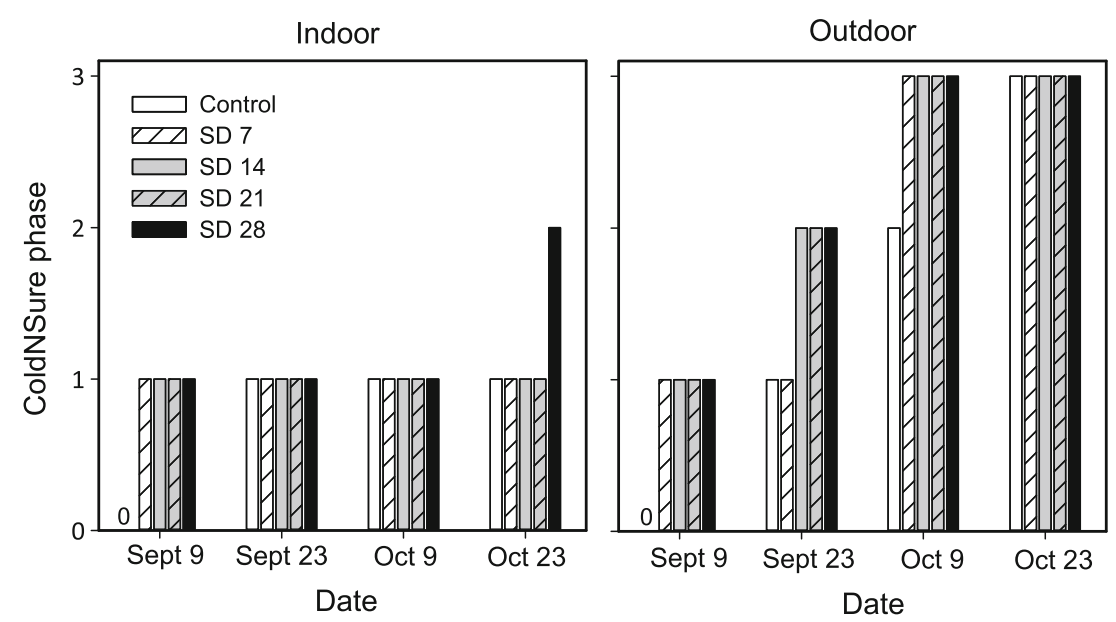

Fig. 6 ColdNSure ${ }^{\mathrm{TM}}$ freezing tolerance phases (adapted from Balk et al. 2007) at different dates of sampling (Sept. 9, Sept. 23, Oct. 9, Oct. 23) for control and SD (short day) treated (11 h light; $13 \mathrm{~h}$ night) seedlings from both indoor and outdoor growth environments. ColdNSure ${ }^{\mathrm{TM}}$ phase $0=$ cold sensitive; the indicator profiles match the profiles of lots that are actively growing and no sign of freezing tolerance could be recognized. Phase $1=$ developing freezing tolerance; early signs of freezing tolerance development can be recognized. Phase

2 = developing freezing tolerance; tolerance level approaches full freezing tolerance. Phase 3 = freezing tolerant; the indicator profiles match the profiles of lots that have ceased growth and that are fully tolerant, ready for lifting and storage. Each sampling date, eight apical buds were collected from the controls and each SD treatment from both growing environments and then analyzed for gene expression as one general sample

outdoor growth environment had broken bud on April 3 compared to control seedlings indoors.

\section{Discussion}

Our results suggest that the duration of SD treatment can be reduced compared to normal practice (4-5 weeks), but this depends on whether the treatment objective is to stop growth or to make seedlings freezing tolerant and storable at an early date. In our study, the seedlings only required 1 week of SD treatment for initiation of apical shoot growth cessation.

Similar results were obtained by Dormling et al. (1968), Dormling (1973, 1979, 1993), Ekberg et al. (1979), Konttinen et al. (2003, 2007), Kohmann and Johnsen (2007), as well as Fløistad and Granhus (2013).

Activity of dormancy-related genes as identified by Stattin et al. (2011) indicated that the seedlings in our study need at least 14 days of SD treatment, corresponding to a photoperiod of $11 \mathrm{~h}$ for dormancy induction. Here, and in Stattin et al. (2011), a longer duration (21-28 days) of SD treatment resulted in higher activity of the dormancy-related genes (Fig. 5). A deeper state of dormancy reduces the risk of a second bud flush during late autumn (Fløistad and Granhus 2010, 2013).
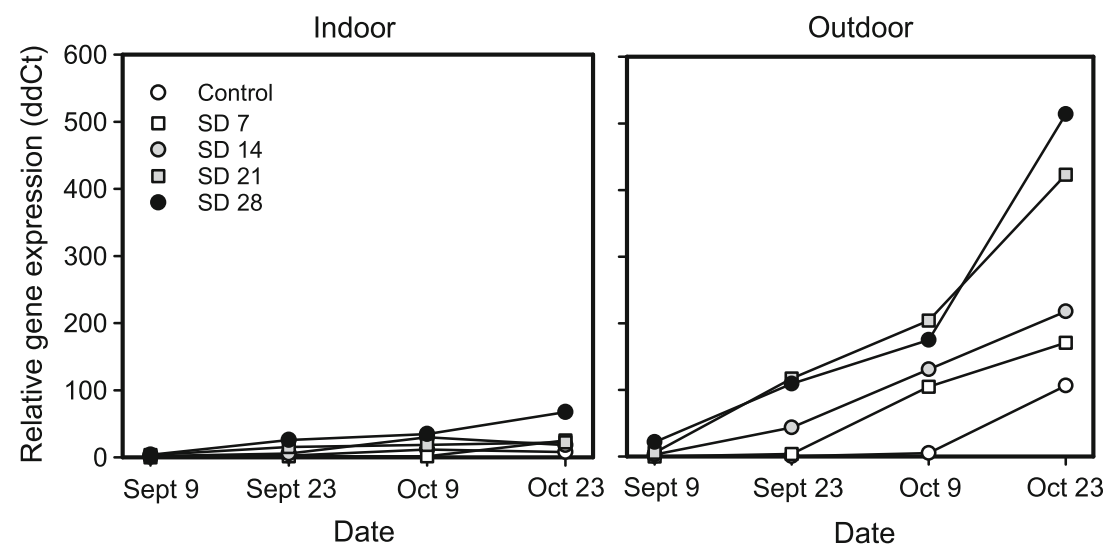

Fig. 7 Expression profile of the gene $\mathrm{CO} 1$ used to indicate freezing tolerance. The level of gene expression is expressed as delta delta threshold cycle $(\mathrm{ddCt})$, which is the relative difference between the gene of interest and reference genes (genes that did not show any significant difference in expression). Measurements were performed at four different occasions, Sept. 9, Sept. 23, Oct. 9, and Oct. 23, 2013,

for Norway spruce seedlings previously subjected to SD (short day) treatments with a photoperiod of $11 \mathrm{~h}$ of various lengths $(0,7,14,21$, and 28 days) starting on July 15. After SD treatment, seedlings were either kept indoors or moved outdoors. Each sampling day, eight apical buds were collected from each SD treatment and growing environment and then analyzed for gene expression as one general sample 


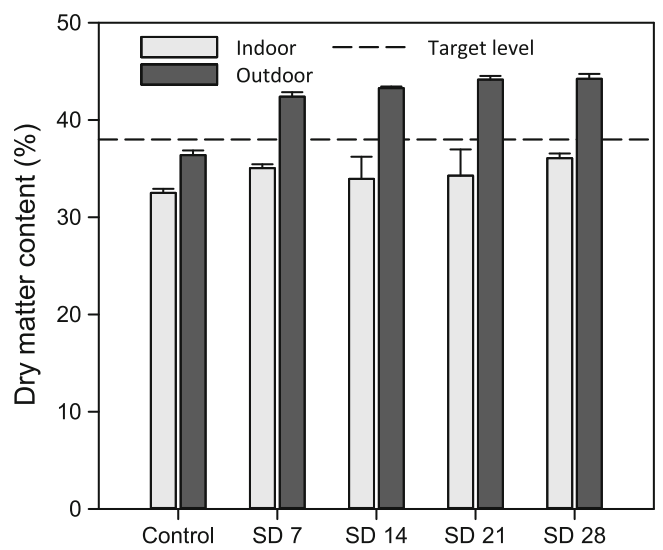

Fig. 8 Dry matter content (DMC \%) for control seedlings and SD (short day) treated (11 h light; $13 \mathrm{~h}$ night) seedlings grown indoors and outdoors measured on Oct. 23, 2013. According to Rosvall-Åhnebrink (1985), the target level for storability of SD-treated Norway spruce seedlings is $\geq 38 \%$ (dashed line). DMC \% values based on shoots from 20 seedlings, $n=4$. Vertical lines represent the standard error
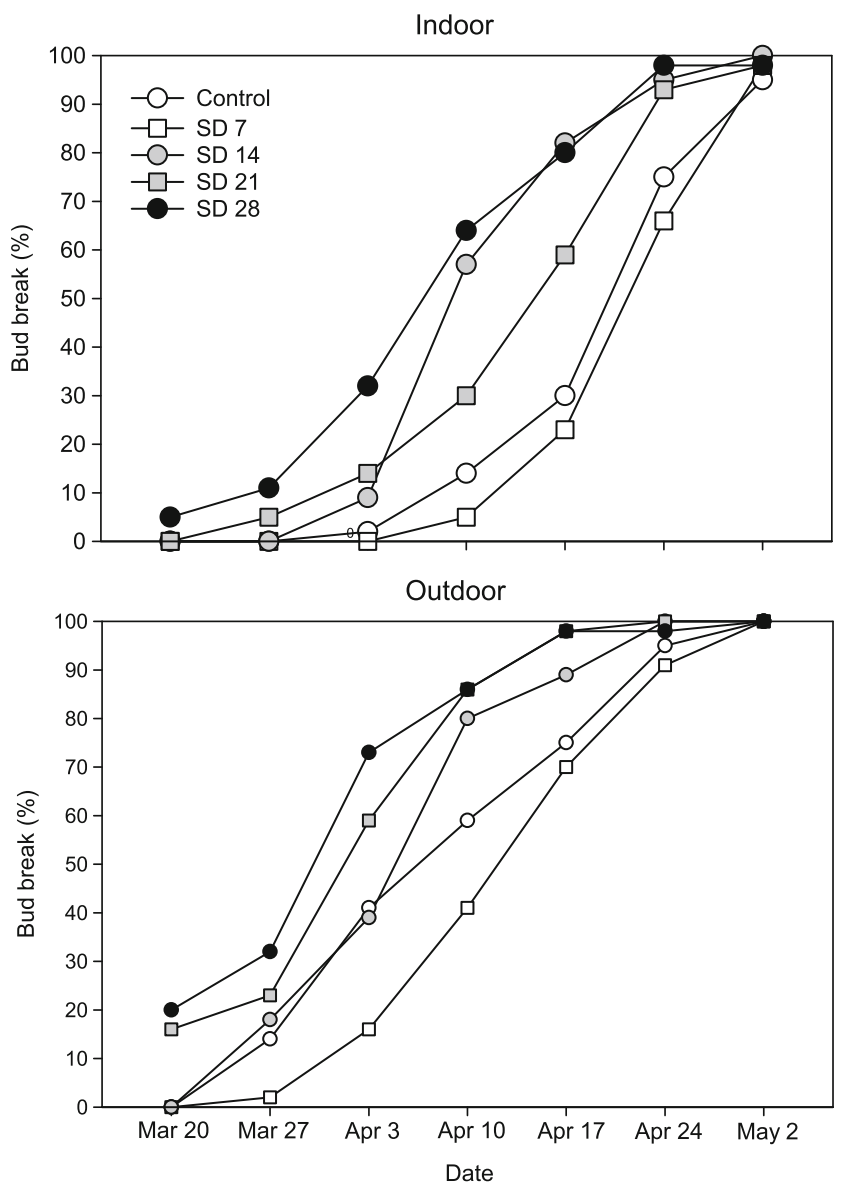

Fig. 9 Apical bud break during the spring of 2014 expressed as percentages and measured weekly between March 20 and May 2. Seedlings had been subjected to SD (short day) treatments (11 h light; $13 \mathrm{~h}$ night) of various lengths starting on July 15, 2013 and thereafter kept indoors or outdoors. Control seedlings in both growing environments were kept under natural day length. Seedlings previously grown and stored in outdoor conditions were transferred indoors on Oct. 28, 2013
In our study, the shorter SD treatments (SD 7 and SD 14) resulted in a later activation not only of dormancy-related genes, but also of genes associated with freezing tolerance compared to the longer SD treatments (SD 21 and SD 28). The results are supported by physiological tests showing that longer SD treatments promote the development of freezing tolerance (Rosvall-Åhnebrink 1982; Konttinen et al. 2003; Kohmann and Johnsen 2007).

Based on the gene expression profiles, Norway spruce seedlings subjected to warmer indoor conditions following termination of SD treatment showed a slower development of dormancy and obtained a lower level of freezing tolerance, compared to seedlings subjected to outdoor conditions. During September 3-25, the control system for regulation of temperature in the greenhouse was not functioning satisfactorily, which resulted in a minimum temperature of about $21{ }^{\circ} \mathrm{C}$ (Fig. 2). This could be one of the reasons for the weak and delayed development of freezing tolerance among seedlings kept indoors (Fig. 6). As concluded by Weiser (1970), Heide (1974), Christersson (1978), and Dormling and Lundkvist (1983), both temperature and photoperiod are important factors affecting dormancy induction and development of freezing tolerance as shown in our study. Our results suggest that warmer autumns associated with climate change could cause problems with the winter hardening processes of seedlings, which can make autumn planting hazardous due to risk of late-season frost. It may also delay the time point when seedlings are considered ready for long-term freezer storage (Stattin et al. 2000).

\subsection{Shoot growth}

During the first week of SD treatment, there was no significant difference in shoot growth between SD-treated seedlings and untreated control seedlings indoors. Thus, shoot growth termination requires time to take effect following initial SD treatment stimuli. Thereafter, all SD-treated seedlings had reduced shoot growth compared to control seedlings in both indoor and outdoor growth environments. By the third week, almost no shoot growth was detected for any SD treatments as similarly reported by Kohmann and Johnsen (2007).

Several studies suggest that less than 2 weeks of SD treatment is enough to terminate apical shoot growth (Dormling et al. 1968; Heide 1974; Konttinen et al. 2003; Fløistad and Granhus 2013). Our results indicate that 7 days of SD treatment is as effective as longer SD treatments to stop apical shoot growth. Further, other provenances of Norway spruce than used in this study as well as different starting dates of SD treatment could affect seedling shoot growth patterns (see, e.g., Fløistad and Granhus 2013). Outdoor-grown control seedlings of the local provenance of Norway spruce used for this experiment still exhibited some shoot elongation as late as the third week of September indicating that the seedlings 
would still be sensitive to frost exposure at this time. These results were confirmed by our ColdNSure ${ }^{\mathrm{TM}}$ test (Fig. 6) and determination of DMC (Fig. 8). It has been shown that SD treatment regulates growth (Fløistad and Granhus 2013) and development of freezing tolerance (Konttinen et al. 2007; Kohmann and Johnsen 2007). These physiological reactions to SD treatment can be explained by the gene expression patterns for dormancy and freezing tolerance, as exhibited in our study.

\subsection{Bud set and bud size}

Bud set and bud development are well known to be an energyconsuming process, which is stimulated by, e.g., high temperature (Dormling 1973; Olsen et al. 2014). Shorter SD treatment (SD 7) resulted in earlier set of visible buds for a higher frequency of seedlings compared to the longer (SD 14, SD 21 and SD 28) treatments both indoors and outdoors (Table 1). In our case, a possible explanation for the later development of visible buds and the smaller buds (Fig. 4) of seedlings enduring longer periods of SD treatment is lack of photosynthetic light rather than low temperatures. As it was hard to visually detect the small buds from the longer SD treatments, it is possible that there in fact were no differences in timing of bud set among the different SD treatments in this study. Despite the fact that control seedlings in our study showed terminal shoot growth late in the season compared to SDtreated seedlings, they still developed somewhat larger buds than seedlings from the longer SD treatments (Fig. 4). These results indicate that light intensity during the first stages of bud development is important for further increasing bud size and emphasize the importance of not exaggerating the length of dark periods during SD treatment. It is well known that temperature and light intensity are major factors driving bud development for spruce species and that treatments such as SD affect bud size and development of needle primordia, which can affect apical shoot growth the forthcoming spring (sensu Grossnickle 2000).

\subsection{Autumn reflushing and bud break in spring}

In our study, there were no signs of reflushing for the longer durations $(14,21$, or 28 days) of SD treatment, whereas reflushing appeared among control and SD 7 treated seedlings. Our results confirm earlier studies by Konttinen et al. (2007), Luoranen et al. (2009), as well as Fløistad and Granhus (2013) showing that short or no periods of SD treatment may increase the risk for reflushing. Fløistad and Granhus (2013) as well as Kohmann and Johnsen (2007) reported that an early starting date (mid or late June) of SD treatment combined with a short (7-14 days) duration increases the risk for reflushing. In our case, due to the relatively late start (mid-July) of SD treatment, the seedlings from SD 7 and SD 14 met a natural night length that was only somewhat shorter than their critical night length, and only a few of the SD 7 treated seedlings showed reflushing. As SD treatment ended, seedlings (especially longer durations of SD treatments) were exposed to natural night lengths long enough to further stimulate dormancy induction. Reflushing mostly occurred among lateral buds of the SD 7 treated seedlings, as similarly shown for silver birch (Betula pendula Roth) (Junttila et al. 2003), which may be due to a lower level of dormancy in lateral compared to apical buds (Fløistad and Granhus, 2013).

Our study showed that all seedlings grown outdoors initiated bud break the following spring about 1-2 weeks earlier than seedlings grown indoors. This is in accordance with results from Olsen et al. (2014), who showed that bud break was delayed in seedlings exposed to high $\left(21^{\circ} \mathrm{C}\right)$ day temperatures compared to lower $\left(15^{\circ}\right.$ or $\left.18{ }^{\circ} \mathrm{C}\right)$ during SD treatment the previous year. The results from our study also indicated that a larger proportion of seedlings from the longer (SD 21 and SD 28) treatments broke bud somewhat earlier compared with the shortest (SD 7) treatment. Konttinen et al. (2003) also showed that Norway spruce seedlings exposed to longer (3-4 weeks) SD treatments with a starting date in July had an earlier bud break the following spring compared to shorter (1-2 weeks) SD treatments. In our study, all SD-treated seedlings had an earlier bud break compared to untreated control seedlings, as reported by others (e.g., Fløistad and Granhus 2010). In our study, seedlings exposed to longer SD treatments and an outdoor climate showed a high activity of the dormancy-related genes. The deeper dormancy induction for these seedlings probably also results in earlier dormancy release, which leads to an earlier bud burst in spring. Our results indicate that the activity of the dormancy-related genes determines the timing of dormancy induction, dormancy release, and forthcoming bud burst. Thus, measurements of gene expression could be used as a tool to predict bud burst in spring, which may help to prevent the risk for spring frost damage (Fløistad and Granhus 2010) in field plantations. However, more research is needed to find out absolute levels of gene expression that copes with physiological reactions of seedlings.

\subsection{Dormancy indicators}

In previous studies, the physiological effects on seedlings from SD treatments were evaluated by measuring different morphological parameters of seedlings (Dormling et al. 1968; Heide 1974; Ekberg et al. 1979; Colombo et al. 1989, 2001; Fløistad and Granhus 2013). In our study, we evaluated relationships between gene expression and seedling physiology and growth. Our results confirm several studies indicating that even short durations of SD treatment (SD 7) are effective to terminate growth. However, the short duration does not stimulate the expression of dormancy or freezing tolerance-related genes as much as the 
longer SD treatments. As outdoor-grown seedlings showed a higher level of gene expression compared to indoor-grown seedlings, apparently cool temperatures are needed to promote rapid dormancy development in addition to short days. Colombo et al. (1989) also found that dormancy development is stimulated by SD treatment combined with fluctuating ambient temperatures in black spruce seedlings. As gene expression decreased or stabilized after an early termination of SD treatment, our results emphasize the importance of continuing SD treatment to further stimulate dormancy induction. If SD treatment starts early in the season, e.g., at the end of June, the seedlings will be exposed to long natural day lengths after the termination of SD treatment. The recommendation from Kohmann and Johnsen (2007) is not to start SD treatment too early or else this may increase the risk for reflushing and reduce development of freezing tolerance. The starting date would clearly have an effect on gene expression, and the extent to which this occurs warrants further research. Measurements of the expression of dormancy-related genes could possibly be used as a tool in forest tree nurseries to establish when SD treatment can be terminated. Our results are promising, but further studies are required to determine the appropriate threshold values either to stop growth or to make seedlings storable at an early date. A similar test to determine these values could be developed as for the ColdNSure ${ }^{\mathrm{TM}}$ test (Joosen et al. 2006; Balk et al. 2008).

A system for continuous measurements of shoot growth during blackout could also possibly be developed to predict when $\mathrm{SD}$ treatment can be terminated. Further research is needed to determine the time space between the termination of apical shoot growth and initiation of dormancy. Our study indicates that to obtain an effective stimulus of dormancy, SD treatment must proceed for at least 1-2 weeks after termination of shoot growth (see Figs. 3 and 5). Among the genes tested, LN3 and LN6 generally showed a slower increase in time and lower expression levels than $L N 2$ and $L N 4$. Therefore, $L N 2$ and $L N 4$ could better serve as early indicators of dormancy.

\subsection{Freezing tolerance}

The ColdNSure ${ }^{\mathrm{TM}}$ test used in our study for estimating freezing tolerance is based on gene expression of several freezing tolerance-related genes such as $\mathrm{CO}$ (Fig. 7). Longer SD treatments resulted in higher levels of gene expression for $\mathrm{CO}$ and this trend was similar for $\mathrm{CO} 4, \mathrm{CO}, \mathrm{CO} 9$, and $\mathrm{CO} 10$, demonstrating that seedlings can be cold stored earlier after receiving a longer period of SD treatment (21-28 days). This trend was most pronounced for outdoor compared to indoorgrown seedlings showing that outdoor climate conditions strongly impact the development of freezing tolerance, which was also observed for the dormancy-related genes. Comparison of only the control seedlings demonstrates the role that climate conditions play in the development of autumn freezing tolerance as the freezing tolerance-related genes responded much more in outdoor- compared to indoorgrown seedlings. From the October $23 \mathrm{DMC}$ data, it is obvious that none of the seedlings kept indoors reached the target level to be ready for cold storage (Fig. 8) while all seedlings kept outdoors were considered storable (for target levels, see Rosvall-Åhnebrink 1985). The ColdNSure ${ }^{\mathrm{TM}}$ test (Fig. 6) supports the outcome of the DMC test as all indoor treatments had only reached freezing tolerance phase 1 except for SD 28 where seedlings had reached phase 2 . The results from the ColdNSureTM $^{\mathrm{TM}}$ test (Fig. 6) also showed that outdoor-grown seedlings from all SD treatments as well as the control were considered storable on October 23, as they had reached freezing tolerance phase 3 . However, the test also indicated that all SD treatments made outdoor-grown seedlings storable at an earlier date compared to untreated control seedlings. We considered it important to include the DMC test in our study because this test is commonly used in practical nursery operations. However, under certain circumstances, the DMC test may be unreliable to forecast storability as shown by Colombo (1990), Lindström (1996), and Lindström et al. (2014). These observations led to the development of storability tests based on the tolerance to freezing by determining electrolyte leakage (Lindström and Håkansson 1996; Colombo 1997; Brönnum 2005) and eventually the ColdNSure ${ }^{\mathrm{TM}}$ test (Joosen et al. 2006; Balk et al. 2007; Balk et al. 2008).

\section{Conclusion}

Compared to untreated seedlings, all SD treatments in this study exhibited a rapid activation of genes related to dormancy and freezing tolerance, thereby making SD-treated seedlings storable at an earlier date. The effect of SD treatment on dormancy induction and development of freezing tolerance determined by molecular tests were most obvious for the longer SD treatments (SD 21 and 28), but there were still clear effects for the shorter SD treatments. Results from our observations of the expression of genes selected to measure dormancy and freezing tolerance emphasize the importance of controlling temperature and photoperiod to produce seedlings that can withstand long-term frozen storage. Our DMC and ColdNSure $^{\mathrm{TM}}$ tests indicate that seedlings kept indoors at high night and day temperatures after termination of SD treatment will not develop sufficient freezing tolerance for safe autumn planting or frozen storage. To accomplish this goal within a reasonable time, local provenances of Norway spruce need to be SD treated in combination with normal outdoor climate conditions. Decisions regarding when it is suitable to terminate SD treatment in the nursery could be either based on the expression of dormancy-related genes, or indirectly according to when shoot growth stops. Our results indicate that an early and continuous activation of dormancy-related genes results in a reduced risk for reflushing, an early of development of 
tolerance to freezing and storability and an early timing of bud break in spring.

Generally, our results suggest that a warmer climate during autumn may adversely affect development of dormancy and freezing tolerance of seedlings. Molecular tests open up possibilities to forecast plant reactions from environmental changes. With further research, they may serve as tools for better understanding factors influencing the phenology of plants and provide decision support in nursery management.

Acknowledgements Thanks to Marianne Vemhäll for help with laboratory work. Also thanks to Anders Lindgren, Bergvik Skog AB, Nässja nursery for providing the seedlings used in the experiments. Thanks to Claudia von Brömssen for her help with the statistics and to Claes Hellqvist who helped creating the figures. We appreciate the constructive comments given by the anonymous reviewers.

\section{Compliance with ethical standards}

Funding This study was supported by the Knowledge Foundation, Bergvik Skog Plantor AB, SCA Skog AB Norrplant, Svenska Skogsplantor AB, Södra Skogsplantor AB, Dalarna University, and the Swedish University of Agricultural Sciences.

Open Access This article is distributed under the terms of the Creative Commons Attribution 4.0 International License (http:// creativecommons.org/licenses/by/4.0/), which permits unrestricted use, distribution, and reproduction in any medium, provided you give appropriate credit to the original author(s) and the source, provide a link to the Creative Commons license, and indicate if changes were made.

\section{References}

Anders S, Huber W (2010) Differential expression analysis for sequence count data. Genome Biol 11:R106

Asante DKA, Yakovlev IA, Fossdal CG, Holefors A, Opseth L, Olsen JE, Junttila O, Johnsen Ø (2011) Gene expression changes during short day induced terminal bud formation in Norway spruce. Plant Cell Environ 34:332-346

Balk PA, Brönnum P, Perks M, Stattin E, van der Geest LHM, van Wordragen MF (2007) Innovative cold tolerance test for conifer seedlings. USDA Forest Service proceedings RMRS-P-50, pp 9-14

Balk PA, Haase DL, Van Wordragen MF (2008) Gene activity test determines cold tolerance in Douglas-fir seedlings. USDA Forest Service proceedings RMRS-P-57, pp 140-148

Brönnum P (2005) Assessment of seedling storability of Quercus robur and Pinus sylvestris. Scand J For Res 20:26-35

Christersson L (1978) The influence of photoperiod and temperature on the development of frost hardiness in seedlings of Pinus Silvestris and Picea abies. Physiol Plant 44:288-294

Christersson L, von Fircks HA (1988) Injuries to conifer seedlings caused by simulated summer frost and winter desiccation. Silva Fenn 22: 195-201

Clapham DH, Dormling I, Ekberg I, Eriksson G, Qamaruddin M, VincePrue D (1998) Latitudinal cline of requirement for far-red light for the photoperiodic control of budset and extension growth in Picea abies (Norway spruce). Physiol Plant 102:71-78

Clapham DH, Ekberg I, Little C, Savolainen O (2001) Molecular biology of conifer frost tolerance and potential applications to tree breeding.
In: Bigras FJ, Colombo SJ (eds) Conifer cold hardiness. Kluwer, Dordrecht, pp 187-219

Colombo SJ (1990) Bud dormancy status, frost hardiness, shoot moisture content, and readiness of black spruce container seedlings for frozen storage. J Am Soc Hortic Sci 115:302-307

Colombo SJ (1997) Frost hardening spruce container stock for overwintering in Ontario. New For 13:449-467

Colombo SJ, Glerum C, Webb DP (1989) Winter hardening in first-year black spruce (Picea mariana) seedlings. Physiol Plant 76:1-9

Colombo SJ, Menzies MI, O'Reilly C (2001) Influence of nursery cultural practices on cold hardiness of coniferous forest tree seedlings. In: Bigras FJ, Colombo SJ (eds) Conifer cold hardiness. Kluwer, Dordrecht, pp 223-252

Dormling I (1973) Photoperiodic control of growth and growth cessation in Norway spruce seedlings. IUFRO division 2 working party 2.01 .4 growth processes. Symposium on dormancy in trees, 5-9 Sept 1973, Kórnik, pp 1-16

Dormling I (1979) Influence of light intensity and temperature on photoperiodic response of Norway spruce provenances. IUFRO Norway spruce meeting S 2.03.11-S 2.02.11, Bucharest, pp 398-408

Dormling I (1982) Frost resistance during bud flushing and shoot elongation in Picea abies. Silva Fenn 16:167-177

Dormling I (1993) Bud dormancy, frost hardiness, and frost drought in seedlings of Pinus sylvestris and Picea abies. In: Li PH, Christersson L (eds) Advances in plant cold hardiness. CRC Press, Boca Raton, pp 285-298

Dormling I, Lundkvist K (1983) Vad bestämmer skogsplantors tillväxt och härdighet i plantskolan? Sveriges lantbruksuniversitet, Skogsfakta. Biologi Och Skogsskötsel 8:1-6 (in Swedish)

Dormling I, Gustafsson Å, Von Wettstein D (1968) The experimental control of the life cycle in Picea abies (L.) karst. 1. Some basic experiments on the vegetative cycle. Silvae Genetica 17:44-64

Ekberg I, Eriksson G, Dormling I (1979) Photoperiodic reactions in conifer species. Holarct Ecol 2:255-263

Fløistad IS, Granhus A (2010) Bud break and spring frost hardiness in Picea abies seedlings in response to photoperiod and temperature treatments. Can J For Res 40:968-976

Fløistad IS, Granhus A (2013) Timing and duration of short-day treatment influence morphology and second bud flush in Picea abies seedlings. Silva Fenn 47. Doi:10.14214/sf.1009

Fushigami LH, Nee CC (1987) Degree growth stage model and restbreaking mechanisms in temperate woody perennials. Hortic Sci 22:836-845

Greer DH, Menzies MI, Warrington IJ (2001) Cold hardiness of Radiata pine (Pinus radiata D. Don). In: Bigras FJ, Colombo SJ (eds) Conifer cold hardiness. Kluwer, Dordrecht, pp 555-573

Grossnickle SC (2000) Ecophysiology of northern spruce species: the performance of planted seedlings. NRC Research Press, Ottawa, $p$ 409

Hannerz M (1994) Damage to Norway spruce (Picea abies (L.) karst) seedlings caused by late spring frost. Forestry Research Institute of Sweden, Uppsala Rep No 5

Heide OM (1974) Growth and dormancy in Norway spruce ecotypes (Picea abies). 1. Interaction of photoperiod and temperature. Physiol Plant 30:1-12

Holliday JA, Ralph SG, White R, Bohlmann J, Aitken SN (2008) Global monitoring of autumn gene expression within and among phenotypically divergent populations of Sitka spruce (Picea sitchensis). New Phytol 178:103-122

Jacobs DF, Davis AS, Wilson BC, Dumroese RK, Goodman RC, Salifu KF (2008) Short-day treatment alters Douglas-fir seedling dehardening and transplant root proliferation at varying rhisosphere temperatures. Can J For Res 38:1526-1535

Joosen RVL, Lammers M, Balk PA, Brönnum P, Konings MCJM, Perks M, Stattin E, Van Wordragen MF, Van der Geest LHM (2006) Correlating gene expression programs to physiological parameters 
and environmental conditions during cold acclimation of pine (Pinus sylvestris). Tree Physiol 26:1297-1313

Junttila O, Nilsen J, Igeland B (2003) Effects of temperature on the induction of bud dormancy in ecotypes of Betula pubescens and Betula pendula. Scand J For Res 18:208-217. doi:10.1080/ 02827580308624

Kohmann K, Johnsen Ø (2007) Effects of early long-night treatment on diameter and height growth, second flush and frost tolerance in twoyear-old Picea abies container seedlings. Scand J For Res 22:375383

Konttinen K, Rikala R, Luoranen J (2003) Timing and duration of shortday treatment of Picea abies seedlings. Balt For 9:2-9

Konttinen K, Luoranen J, Rikala R (2007) Growth and frost hardening of Picea abies seedlings after various night length treatments. Balt For 13:140-148

Krutzsch P (1973) Norway spruce development of buds. Internal report. International Union of Forest Research Organizations, Vienna IUFRO S2.02.11

Lindström A (1996) Freezing temperatures in the root zone-effects on growth of containerized scots pine and Norway spruce seedlings. Scand J For Res 1:371-377

Lindström A, Håkansson L (1996) EC-metoden- ett sätt att bestämma skogsplantors lagringsbarhet. Swedish University of Agricultural Sciences, Dep for yield res stencil nr 95 [In Swedish]

Lindström A, Stattin E, Gräns D, Wallin E (2014) Storability measures of Norway spruce and scots pine seedlings and assessment of poststorage vitality by measuring shoot electrolyte leakage. Scand J For Res 29:717-724

Luoranen J, Rikala R (2015) Post-planting effects of early-season shortday treatment and summer planting on Norway spruce seedlings. Silva Fenn 49. Doi:10.14214/sf.1300

Luoranen J, Konttinen K, Rikala R (2009) Frost hardening and risk of a second flush in Norway spruce seedlings after an early-season shortday treatment. Silva Fenn 43:235-247

MacDonald JE, Owens JN (2010) Physiology and growth of containerized coastal Douglas-fir seedlings given different durations of short days to induce dormancy. Hortic Sci 45:342-346

Mattsson A (1997) Predicting field performance using seedling quality assessment. New For 13:227-252
Olsen JE, Lee Y, Junttila O (2014) Effect of alternating day and night temperature on short day-induced bud set and subsequent bud break in long days in Norway spruce. Front Plant Sci 5:691. doi:10.3389/ fpls.2014.00691

Rosvall-Åhnebrink G (1982) Practical application of dormancy induction techniques to greenhouse-grown conifers in Sweden. In: Scarrat JB, Glerum, C, Plexman CA (eds) Proc Canadian containerized tree seedling symposium. Can Fo. Serv COJFR Symp proc. O-P-10

Rosvall-Åhnebrink G (1985) Invintring av plantor för höstplantering eller vinterlagring [Preparing seedlings for autumn planting or winter storage]. In: Eriksson A, Zimmerman J (eds) Skogsskötsel i södra Sverige Jönköping 16-17 januari 1985.Silviculture in southern Sweden Jönköping 16-17 January 1985; Skogsfakta konferens nr, vol 7. Swedish University of Agricultural Sciences, Uppsala, pp 3337 In Swedish

SAS Institute, Inc. (2002-2008) SAS/STAT software version 9.4. SAS Institute, Inc., Cary

Sögaard G, Johnsen Ö, Nilsen J, Junttila O (2007) Climatic control of bud burst in young seedlings of nine provenances of Norway spruce. Tree Physiol 28:311-320

Stattin E, Hellqvist C, Lindström A (2000) Storability and root freezing tolerance of Norway spruce (Picea abies) seedlings. Can J For Res 30:964-970

Stattin E, Lindström A, Verhoef N, Balk P (2011) Quality management for vital forest tree seedlings. Final Report. Project no: P33854-1, Eurostars E!4247 QFORS. http://du.diva-portal.org/smash/record. jsf?pid=diva2:523294

Stattin E, Verhoef N, Balk P, van Wordragen M, Lindström A (2012) Development of a molecular test to determine the vitality status of Norway spruce (Picea abies) seedlings during frozen storage. New For 43:665-678

Sutinen S, Partanen J, Viherä-Aarnio A, Häkkinen R (2012) Development and growth of primordial shoots in Norway spruce buds before visible bud burst in relation to time and temperature in the field. Tree Physiol 00:987-997. doi:10.1093/treephys/tps063

Weiser CJ (1970) Cold resistance and injury in woody plants. Science 169:1269-1278 